\title{
Medicinal herbs with anti-depressant effects
}

\author{
Mahbubeh Setorki ${ }^{*}$ \\ Department of Biology, Izeh Branch, Islamic Azad University, Izeh, Iran
}

\section{A R T I C L E I N F O}

Article Type:

Review

Article History:

Received: 10 November 2018

Accepted: 24 January 2019

Keywords:

Depression

Clinical trials

Medicinal plants

Herbal medicines

\begin{abstract}
A B S T R A C T
Depression is a life-threatening chronic illness which affects people worldwide. Drugs used to treat this disease have multiple side effects and may cause drug-drug or drug-food interactions. Additionally, only $30 \%$ of patients respond adequately to the existing drugs and the remaining do not achieve complete recovery. Thus, finding effective treatments that have adequate efficacy, fewer side effects and lower cost seem to be necessary. The purpose of this study was to review animal and double-blind clinical studies on the anti-depressant effects of medicinal herbs. In this study, validated scientific articles indexed in PubMed, SID, Web of Science and Scopus databases were reviewed. A database search was performed using the following terms: clinical trials, depression, major depressive disorder, essential oil, extract and medicinal plant. Positive effects of a number of herbs and their active compounds such as St John's-wort, saffron, turmeric, ginkgo, chamomile, valerian, Lavender, Echium amoenum and Rhodiola rosea L. in improvement of symptoms of mild, moderate or major depression have been shown in clinical trials. The above plants show antidepressant effects and have fewer side effects than synthetic drugs. Hence, they have the potential to treat patients with depression.
\end{abstract}

Implication for health policy/practice/research/medical education:

Medicinal plants have the potential to treat patients with depression.

Please cite this paper as: Setorki M. Medicinal herbs with anti-depressant effects. J Herbmed Pharmacol. 2020;9(4):309-317. doi: 10.34172/jhp.2020.39.

\section{Introduction}

Depression is a common, debilitating, and dangerous disease that affects the person's life and behavior and influences many people all over the world. Depression currently affects $20 \%$ of the global population and is considered as one of the leading causes of death. According to the World Health Organization, depression is ranked fourth among the health problems and major depressive disorder is predicted to become the second most debilitating factor in the world by $2020(1,2)$. According to the research conducted in Iran, about 7 million people suffer from depression and about 15\%$25 \%$ of the population experience depression at different degrees (from mild to severe) (3). In addition to affecting individual performance in various contexts such as education, occupation, and interpersonal relationships, depression increases the rates of misdemeanor and substance abuse. Moreover, depression increases the risk of suicide. The risk of suicide among patients with depression appears to be more than other mental disorders (4).
Studies have shown that changes in brain monoamine level, hypothalamic-pituitary-adrenal (HPA) axis dysfunction, immune-inflammatory processes, oxidative and nitrative stress, neurodegeneration, and inhibition of neurogenesis are involved in the pathogenesis of depression. Various drugs have been introduced for the treatment of depression, including selective serotonin reuptake inhibitors, tricyclic antidepressants, serotoninnorepinephrine reuptake inhibitors, and monoamine oxidase inhibitors (5).

Clinical trials show that most patients do not like to take the medication due to their side effects. Studies also show that some available drugs are effective only in half of the patients and others do not achieve complete remission (6). Therefore, finding effective treatments for depression with adequate efficacy, fewer side effects and lower cost is one of the active fields of research today (4). In this regard, medicinal plants which show wide spectrum of therapeutic properties have attracted considerable attention as supplementary drug or even alternative treatment for depression all over the world (7). The aim 
of this study was to review animal and clinical studies performed on anti-depressant effects of medicinal plants.

\section{Methods}

In this study, validated scientific articles indexed in PubMed, SID, Web of Science and Scopus databases were reviewed. A database search was performed using the following terms: clinical trials, depression, major depressive disorder, essential oil, extract and medicinal plant.

\section{Results}

Until today, numerous studies have shown the antidepressant effects of medicinal plants in animal models with fewer studies on human. Plants that have shown considerable activities in animal studies and are used in clinical trials are presented here.

\section{Hypericum perforatum L. (St John's wort)}

Common Saint John's wort with the scientific name of Hypericum perforatum $\mathrm{L}$. is an herbaceous perennial plant of the family Hypericaceae, which is native to Western Europe, Asia, and North Africa. This plant is widely spread in Iran and grows on the hillsides of the Alborz Mountains, Chalus, Mazandaran and western parts of Iran (8). The importance of this plant as an herbal remedy to treat depression has increased significantly in recent years and several studies have been carried out on its antidepressant effects in animal models as well as humane studies (4). The double-blind randomized clinical trials on patients with mild to moderate depression indicated that the St John's wort extract was more effective than placebo and had effects similar to fluoxetine, imipramine, and sertraline. In addition, its side effects were significantly lower in comparison with the above mentioned drugs (8-12). The main effective ingredients of the herb are hyperforin and hypericin, and studies have shown that hyperforin is a superior option to hypericin for anti-depressant activity of the plant (13). Experimental studies have demonstrated that the plant extract is a weak inhibitor of monoamine oxidase enzyme but significantly inhibits the reuptake of synaptic serotonin, dopamine, and norepinephrine. The plant extract has a downregulative effect on betaadrenergic receptors and an upregulative effect on serotonin receptors. It also changes the concentration of neurotransmitters in some parts of the brain. It has been stated that the plant extract adjusts the expression of the genes that control the hypothalamic-pituitaryadrenal axis and reduces the elevated levels of serum adrenocorticotropin and corticosterone (4). In a study conducted on women aged 55 to 65 with depression, it was found that after consuming the hypericin extract, the level of 3-methoxy-4-hydroxyphenylglycol significantly increased. Methoxy-4-hydroxyphenylglycol is a metabolite produced by norepinephrine metabolism and is a marker for anti-depressant response (14). Several pharmaceutical products prepared from this plant include hypericaps, Hypericum STADA, Hypericum 300, and Hypericum Syxyl S. Hypiran drop and Perforan tablet have been made and presented to the market in Iran (13).

\section{Saffron (Crocus sativus L)}

Saffron with the scientific name of Crocus sativus L., from the family Iridaceae, is one of the most expensive spices in the world. In addition to traditional value as a food additive, it also has a number of therapeutic effects. In general, the saffron, its extracts and tinctures have been used in traditional medicine as antispasmodic, analgesic, anti-inflammatory, sedative, carminative, sweat enhancer, expectorant, stimulant, gastric strengthener, sexual desires stimulant and as an agent to develop early menstruation. The antidepressant effects of the aqueous and hydroalcoholic extracts of saffron have been demonstrated in animal models $(15,16)$. In a randomized double-blind clinical trial, 40 patients with mild to moderate depression were treated with hydroalcoholic extract of saffron at a dose of $30 \mathrm{mg} / \mathrm{d}$ or fluoxetine at a dose of $20 \mathrm{mg} / \mathrm{d}$. After 6 weeks of treatment, saffron caused considerable improvement similar to that of fluoxetine. In addition, no significant differences were found between the two groups in terms of side effects. One of the side effects reported for saffron is an increased risk of bleeding; but in this study, saffron didn't cause abnormal bleeding (17). In a clinical trial, the saffron capsule at a dose of $30 \mathrm{mg} / \mathrm{kg}$ showed antidepressant effects similar to imipramine $(100 \mathrm{mg} / \mathrm{kg})$ in patients with mild to severe depression. The anticholinergic effects such as dry mouth and sedation were seen in the imipramine group, which were significantly higher than those in saffron group (18). In another study on women with premenstrual syndrome, the daily consumption of saffron capsules at a dose of 30 $\mathrm{mg} / \mathrm{kg}$ significantly reduced the symptoms of the disease as well as the depression. Although the side effects of saffron were higher than the placebo, their difference was not significant (7). Regarding the mechanism of antidepressant activity, it is proposed that two active compounds of saffron, including safranal and crocin, inhibit the reuptake of dopamine, norepinephrine, and serotonin (15).

\section{Rhodiola rosea $\mathrm{L}$.}

Rhodiola rosea L., from Crassulaceae family, naturally grows in Europe, Asia, and North America. This herb has long been used in the traditional medicine of these areas to treat various disorders, including anxiety and depression. Currently, $R$. rosea is known as an adaptogen plant, which increases the resistance to stress and causes physical vitality (5). Studies have shown that the cotherapy of patients with depression by $R$. rosea and tricyclic antidepressants induces a better antidepressant 
effect than the traditional antidepressant drugs alone (19). In a randomized double-blind clinical trial, Darbinyan et al examined the antidepressant effects of $R$. rosea in patients with mild to chronic depression. Patients (90 subjects) were divided into two groups of intervention (extract at doses of 340 and $640 \mathrm{mg} / \mathrm{d}$ ) and a group of placebo. The extract at both doses significantly improved the general depression as well as insomnia and emotional instability, while the placebo had no significant effects. None of the groups complained about the side effects of the medication (20). In a double-blind clinical trial study by Mao et al, the antidepressant efficacy of $R$. rosea was evaluated in comparison with sertraline. A number of 57 patients with major depression were divided into three groups of extract, sertraline and placebo. Although, the activity of the extract was lower than that of sertraline but it caused fewer adverse reactions compared to sertraline (30\% versus 63\%) (21). The extract of this plant shows antidepressant activity through increasing the levels of serotonin, dopamine and norepinephrine in the different parts of the brain $(5,22)$.

\section{Curcumin}

Curcumin is a natural chemical compound found in turmeric (Curcuma longa Linn). Curcumin has shown significant antidepressant effects in a large number of animal models of depression. However, its effectiveness in clinical trials is lower due to low digestive absorption (23). In a double-blind clinical trial, 60 patients with major depression were divided into three groups receiving fluoxetine (20 mg), curcumin (1000 mg) and their combination. After 6 weeks of treatment, the combination of fluoxetine and curcumin resulted in a reduction of $77.8 \%$ of the symptoms, which was higher compared to the fluoxetine (64.7\%) and curcumin (62.4\%) alone. In this study, curcumin was well tolerated by the patients and caused fewer side effects compared to the fluoxetine (1). In a double-blind clinical trial by Lopresti et al, the effect of daily curcumin intake was studied on patients with major depressive disorder. Fifty-six patients were randomly assigned to curcumin (500 $\mathrm{mg}$ twice daily) or placebo groups. After 4 weeks of treatment, no significant difference was found between the two groups in terms of depressive symptoms remission. However, after 8 weeks, the depressive symptoms significantly improved in the curcumin group. In addition, curcumin induced better effects in the subgroup of atypical major depression (24). In another clinical trial, forty patients with first episode of depression participated in a 5-week, double-blind, randomized, placebo-controlled study. The subjects were treated with either $500-\mathrm{mg} / \mathrm{d}$ curcumin or placebo together with antidepressants (escitalopram or venlafaxine) during August 2010 until June 2011. Result showed significant decrease in the symptoms of both groups and the patients in curcumin group showed a better recovery. None of the patients complained about the side effects of the medications (25). Based on the reports of studies, curcumin improves the symptoms of depression by influencing the biological mechanisms involved in depression, including monoaminergic activity, inflammatory process, oxidative and nitrative pathways and activity of the HPA axis. Curcumin also increases the neurogenesis in the frontal cortex and hippocampus of mice exposed to depression (23).

\section{Maidenhair tree or Ginkgo (Ginkgo biloba)}

Ginkgo, from the Ginkgoceae family, is a large and deciduous tree with fan-shaped leaves. It is an indigenous tree of China, Japan and Korea, but is now grown in many parts of the world. The seeds and leaves of the plant have been widely used in traditional Chinese medicine for the treatment of various diseases. Pharmacologically, the pure extract of the plant leaves has the potential to open arterial arteries and activate the blood circulation in the arteries, which itself provides more perfusion to the tissues. The leaf extract of the herb increases the blood flow to the brain, and thus, improves memory and intellectual ability. Currently, ginkgo is one of the most popular herbs in Germany and in the United States. In these countries, ginkgo extract is marketed under the brands of Rokan and Tanakan and is prescribed for age-related mental and physical illnesses (26). In Iran, ginkgo tablets are sold to improve and strengthen the memory (27). The antidepressant effects of ginkgo herb have been studied in a number of clinical trials. In a double-blind clinical trial, 81 patients with major depressive disorder were randomly assigned into two groups of routine electroconvulsive therapy with ginkgo pills ( $40 \mathrm{mg} / 8 \mathrm{~h}$ ) and control group was treated with placebo for electroconvulsive therapy period ( 2 weeks). After intervention, the extract group had a better cognitive status and less depression compared with the placebo group (27). In another double-blind clinical trial, 27 patients with seasonal mood disorder were treated with ginkgo pills or placebo for 10 weeks. Based on the study results, no significant difference was found between the two groups in terms of depression score, which might be related to the small size of the samples (28). Clinical studies have also reported that the co-therapy of patients with major depression by ginkgo extract $(240 \mathrm{mg} / \mathrm{d})$ and trimipramine $(200 \mathrm{mg})$ resulted in a significant reduction in the sleep disorders induced by trimipramine (29). The ginkgo extract also improves sexual dysfunctions caused by antidepressants in patients with major depression (30).

\section{Chamomile}

Chamomile dried flowers were known as an effective herbal medicine in Rome, Greece and ancient Egypt. In the traditional medicine of these countries, chamomile has been used to relieve pain, treat digestive disorders and heal 
wound or injury. There are different varieties of chamomile, but two species of German chamomile (Matricaria recutita) and Roman chamomile (Chamaemelum nobile) are the most widely used species throughout the world. German chamomile has been shown to improve the symptoms of depression in animal models as well as human (6). In a double-blind clinical trial by Amsterdam et al, 57 patients with mixed anxiety and depressive disorder (MADD) were treated with placebo or chamomile capsules $(220 \mathrm{mg} / \mathrm{d})$ for 8 weeks. Nineteen patients had MADD, 16 had anxiety disorder with a history of depression, and 22 had anxiety disorder without a history of depression. After 8 weeks of treatment, the depression scores decreased significantly in the chamomile group compared to the placebo group. In addition, patients with MADD responded more strongly to chamomile than other patients (6). In another controlled trial, the consumption of chamomile tea significantly improved the quality of sleep and depression in women during the postpartum period (31). Regarding the mechanisms involved in the antidepressant effects of chamomile, it is suggested that chamomile extract and its active compounds such as apigenin and quercetin modulate norepinephrine, dopamine, serotonin, and GABA messaging, regulate the activity of hypothalamicpituitary-adrenal axis, and inhibit monoamine oxidase enzyme activity (6). Chamomile is classified by US Food and Drug Administration as GRAS substance and its safety has been demonstrated in children, pregnant women, and people with kidney and liver diseases. Chamomile essential oil is commonly used for aromatherapy in people with sleep disorders and anxiety. Its tea is one of the most popular products which have sedative effects. Its tablets with an authorized dose of 9-15 g/d are prescribed for sedation and control of sleep disorders (32). Also, the results of recent studies on rats showed that the ethanolic extract of chamomile had a restorative effect on memory deficits and motor-coordination problems and may be useful in patients with behavioral problems. The memory enhancement effect of chamomile extract may be due to the cleansing properties of free radicals, which can be produced by the active compounds present in the extract (33).

\section{Valerian (Valeriana officinalis L.)}

Valerian with the scientific name of Valeriana officinalis L. belongs to the Caprifoliaceae family. This plant has a pleasant smell and its roots are commonly used in traditional medicine. The root of valerian has been used in Iranian traditional medicine as neurological sedative, hypnotic, anticonvulsant, antidepressant, food digester and anti-colic agent. The beneficial effects of valerian have been shown in several animal models of depression. However, few clinical studies have investigated the antidepressant effects of the plant (34). In a study, Müller et al evaluated the antidepressant effects of valerian and
St John's-wort in 2500 patients with mild to moderate depression. The treatment with St John's-wort (600 mg), valerian $(100 \mathrm{mg})$, or their combination $(600 \mathrm{mg}$ of St John's-wort and $500 \mathrm{mg}$ of valerian) significantly improved the symptoms of disease. The combination of valerian and St John's-wort showed better effects than each of them alone. Valerian and St John's-wort were well tolerated by the patients and side effects similar to the placebo were reported for them (35). In addition, the activity of valerian in improving sleep problems and general anxiety disorder have been demonstrated in clinical studies $(34,36)$. The drug products containing valerian include valerian 1000 Herbal Relaxer, ReDormin, Safrocalm Night, and Valerian Plantapol in European countries and Neuragol-coated tablet in Iran, which are sold for relaxation effects and improving the sleep quality; however, they are not licensed by the FDA.

\section{Lavender (Lavandula angustifolia)}

The lavender plant, with the scientific name of Lavandula angustifolia, belongs to the Lamiaceae family and has long played a role in the traditional medicine. Lavender has been used in traditional medicine as analgesic, anti-spasmodic, and sedative. In clinical trials, the aromatherapy with lavender essential oil has been shown to reduce pain, anxiety, depression, and stress (37). In a double-blind clinical trial, 80 patients with mild to moderate depression were assigned to one of two groups: the case group receiving $20 \mathrm{mg} / \mathrm{d}$ of citalopram plus $5 \mathrm{mg}$ of lavender twice daily and the control group receiving 20 mg citalopram twice daily. The depression symptoms were significantly lower in the case group 4 weeks and 8 weeks after the treatment. Both groups complained of dizziness and dry mouth, while no significant difference was found between them in this regard (38). In another double-blind clinical trial, 45 patients with mild to moderate depression were divided into a group receiving lavender drop (60 drops) + placebo tablet, a group receiving imipramine tablet (100 mg) + placebo drop (60 drops), and a group receiving lavender drop (60 drops) + imipramine tablet (100 mg). After 4 weeks, lavender alone caused lower antidepressant effect compared to the imipramine. The antidepressant effects of lavender and imipramine combination were significantly higher than imipramine alone. The imipramine group complained about the anticholinergic side effects such as dry mouth and urinary retention, while the lavender group complained of headache (39).

\section{Echium amoenum}

Iranian Echium with the scientific name of Echium amoenum belongs to the Boraginaceae family and exclusively grows in the Alborz Mountain Range, Iran. In Iran this plant is traditionally used to treat anxiety and to enhance mood. The anxiolytic and antidepressant 
effects of E. amoenum have been shown in clinical studies $(40,41)$. In a double-blind clinical trial, 35 patients with mild to moderate depression were treated with placebo or E. amoenum $(375 \mathrm{mg} / \mathrm{d})$ for 6 weeks. After 4 weeks, depression was significantly reduced in the group treated with E. amoenum. The side effects of E. amoenum did not differ significantly with the placebo (41) (Table 1).

\section{Discussion}

In traditional medicine, several herbs have been recommended to cause relaxation, improve mood, and reduce sleep disorders (42). They include: O. vulgare, $C$. asiatica, C. sativum, C. tinctorius, S. hortensis, P. ginseng, M. recutita, J. officinale, S. barbata, T. serpyllum, $H$. perforatum, A. graveolens, $P$. caerulea, V. officinalis, A. racemosa, $V$. officinalis, $H$. lupulus, $I$. paraguariensis, L. angustifolia, T. begonifolialinden, A. citrodora, $M$. officinalis, R. officinalis, T. vulgaris, and R. gallica. The efficacy of some of these plants such as $H$. perforatum, $M$. recutita, $V$. officinalis, L. angustifolia and E. amoenum has been demonstrated in improving the symptoms of mild to moderate depression in double-blind clinical trials. In addition, the antidepressant effects of $C$. asiatica (42), C. sativum (43), S. hortensis (44), P. ginseng (45), C. tinctorius (46) A. graveolens (47), T. vulgaris ((48), P. caerulea (49), M. officinalis (50), and R. officinalis (51) have been shown in animal models of depression, which provides further areas for research on their efficacy in the clinical studies. A review of double-blind clinical trials revealed that $H$. perforatum, $C$ sativus, $M$. recutita, $V$. officinalis, $L$. angustifolia, and E. amoenum were effective on the symptoms of mild to moderate depression $(9,18,39)$, while curcumin and $G$. biloba relieved the major depression symptoms $(25,29)$ and $H$. perforatum, exhibit antidepressant have been shown to be similar to chemical drugs (8). Some plants such as L. angustifolia and E. amoenum are effective in combination with antidepressant drugs $(22,41)$. In addition, some like C. sativus, G. biloba, and $M$. recutita are useful in reducing the disorders such as sexual disorders and insomnia caused by chemical antidepressants drugs $(7,30,32)$

Clinical studies conducted on the antidepressant effects

Table 1. Medicinal plants with antidepressant activity evaluated in clinical trails

\begin{tabular}{|c|c|c|c|c|c|c|}
\hline Plant & Type of study & $\begin{array}{l}\text { Patients and } \\
\text { depression type }\end{array}$ & Plant used & $\begin{array}{l}\text { Method for } \\
\text { of depression } \\
\text { assessment }\end{array}$ & Finding & Ref. \\
\hline \multirow{4}{*}{$\begin{array}{l}\text { Hypericum } \\
\text { perforatum }\end{array}$} & $\begin{array}{l}\text { Randomized } \\
\text { double-blind } \\
\text { comparative trial }\end{array}$ & $\begin{array}{l}149 \text { elderly with } \\
\text { mild or moderate } \\
\text { depression }\end{array}$ & $\begin{array}{l}\text { St. John's wort extract } \\
\text { (800 mg) / fluoxetine }\end{array}$ & Hamilton Rating Scale & $\begin{array}{l}\text { St. John's wort extract } \\
\text { showed antidepressant } \\
\text { effect similar to fluoxetine }\end{array}$ & (8) \\
\hline & \multirow{2}{*}{$\begin{array}{l}\text { Randomized, } \\
\text { double-blind, } \\
\text { placebo-controlled } \\
\text { study }\end{array}$} & $\begin{array}{l}332 \text { patients with } \\
\text { mild or moderate } \\
\text { depression }\end{array}$ & $\begin{array}{l}\text { WS }^{\circledR} 5570 \text { (600 or } 1200 \\
\mathrm{mg} / \mathrm{d}) / \text { placebo for } 6 \\
\text { weeks }\end{array}$ & Hamilton Rating Scale & $\begin{array}{l}\text { WS }^{\circledR} 5570 \text { ( } 600 \text { or } 1200 \\
\text { mg) showed significant } \\
\text { antidepressant effect } \\
\text { compared to placebo }\end{array}$ & (10) \\
\hline & & $\begin{array}{l}147 \text { patients with } \\
\text { mild or moderate } \\
\text { depression }\end{array}$ & $\begin{array}{l}\text { WS5573 ( } 300 \text { mg with a } \\
\text { content of } 0.5 \text { or } 0.5 \% \\
\text { hyperforin)/placebo for } \\
6 \text { weeks }\end{array}$ & $\begin{array}{l}\text { Hamilton Rating Scale } \\
\text { Depression Self-Rating } \\
\text { Scale }\end{array}$ & $\begin{array}{l}\text { WS5572 (5 \% hyperforin) } \\
\text { showed significant } \\
\text { antidepressant effect } \\
\text { compared to placebo }\end{array}$ & (11) \\
\hline & $\begin{array}{l}\text { Randomised, } \\
\text { double blind, } \\
\text { multicentre, } \\
\text { parallel group trial }\end{array}$ & $\begin{array}{l}263 \text { patients with } \\
\text { moderate depression }\end{array}$ & $\begin{array}{l}1050 \text { mg hypericum } \\
\text { extract ( } 3 \text { times daily)/ } \\
\text { imipramine /placebo }\end{array}$ & $\begin{array}{l}\text { Hamilton Rating Scale, } \\
\text { Clinical global } \\
\text { impressions scale, } \\
\text { Zung's self-rating } \\
\text { depression scale }\end{array}$ & $\begin{array}{l}\text { Hypericum extract was } \\
\text { more effective than } \\
\text { placebo and as effective as } \\
\text { imipramine }\end{array}$ & (12) \\
\hline \multirow{3}{*}{$\begin{array}{l}\text { Crocus } \\
\text { sativus L. }\end{array}$} & $\begin{array}{l}\text { Double-blind, } \\
\text { randomised and } \\
\text { placebo-controlled } \\
\text { trial }\end{array}$ & $\begin{array}{l}\text { Women with } \\
\text { premenstrual } \\
\text { syndrome }\end{array}$ & $\begin{array}{l}\text { Saffron capsule ( } 30 \\
\mathrm{mg} / \mathrm{d} \text { )/placebo for a two } \\
\text { menstrual cycles }\end{array}$ & Hamilton Rating Scale & $\begin{array}{l}\text { Extract showed significant } \\
\text { antidepressant effect } \\
\text { compared to placebo }\end{array}$ & (7) \\
\hline & \multirow{2}{*}{$\begin{array}{l}\text { Double-blind, } \\
\text { single-center } \\
\text { randomized trial }\end{array}$} & $\begin{array}{l}40 \text { patients with } \\
\text { mild to moderate } \\
\text { depression }\end{array}$ & $\begin{array}{l}\text { Saffron extract }(30 \mathrm{mg}) / \\
\text { fluoxetine for } 6 \text { weeks }\end{array}$ & Hamilton Rating Scale & $\begin{array}{l}\text { Extract was effective } \\
\text { similar to fluoxetine }\end{array}$ & (17) \\
\hline & & $\begin{array}{l}30 \text { patients with } \\
\text { major depression }\end{array}$ & $\begin{array}{l}\text { Saffron capsule }(30 \mathrm{mg}) / \\
\text { imipramine for } 6 \text { week }\end{array}$ & Hamilton Rating Scale & $\begin{array}{l}\text { Extract was effective } \\
\text { similar to imipramine }\end{array}$ & (18) \\
\hline \multirow{2}{*}{$\begin{array}{l}\text { Rhodiola } \\
\text { rosea }\end{array}$} & $\begin{array}{l}\text { Randomized } \\
\text { double-blind } \\
\text { placebo-controlled } \\
\text { study }\end{array}$ & $\begin{array}{l}89 \text { patients with mild } \\
\text { to chronic depression }\end{array}$ & $\begin{array}{l}\text { Extract ( } 340 \text { or } 640 \mathrm{mg} \text { )/ } \\
\text { placebo for } 6 \text { weeks }\end{array}$ & $\begin{array}{l}\text { Beck Depression } \\
\text { Inventory, } \\
\text { Hamilton Rating Scale }\end{array}$ & $\begin{array}{l}\text { Both doses showed } \\
\text { significant antidepressant } \\
\text { effect compared to } \\
\text { placebo }\end{array}$ & (20) \\
\hline & $\begin{array}{l}\text { Randomized } \\
\text { double-blind } \\
\text { placebo-controlled } \\
\text { study }\end{array}$ & $\begin{array}{l}57 \text { patients with } \\
\text { major depression }\end{array}$ & $\begin{array}{l}\text { Extract at a dose of } 300 \\
\mathrm{mg} / \text { sertraline for } 12 \\
\text { weeks }\end{array}$ & $\begin{array}{l}\text { Hamilton Rating scale, } \\
\text { Beck Depression } \\
\text { Inventory scale, } \\
\text { Clinical Global } \\
\text { Impression Change }\end{array}$ & $\begin{array}{l}\text { Extract was less effective } \\
\text { than sertraline but had } \\
\text { fewer adverse effect }\end{array}$ & (21) \\
\hline
\end{tabular}


Table 1. Continued

\begin{tabular}{|c|c|c|c|c|c|c|}
\hline Plant & Type of study & $\begin{array}{l}\text { Patients and } \\
\text { depression type }\end{array}$ & Plant used & $\begin{array}{l}\text { Method for } \\
\text { of depression } \\
\text { assessment }\end{array}$ & Finding & Ref. \\
\hline \multirow{3}{*}{$\begin{array}{l}\text { Curcumin } \\
\text { (Curcuma } \\
\text { longa Linn) }\end{array}$} & $\begin{array}{l}\text { Observer-masked } \\
\text { trial }\end{array}$ & $\begin{array}{l}60 \text { patients with } \\
\text { major depression }\end{array}$ & $\begin{array}{l}\text { Curcumin (1000 mg)/ } \\
\text { curcumin+ fluoxetine/ } \\
\text { fluoxetine for } 6 \text { weeks }\end{array}$ & $\begin{array}{l}\text { Hamilton Depression } \\
\text { Rating Scale }\end{array}$ & $\begin{array}{l}\text { Curcumin +fluoxetine } \\
\text { showed better effect } \\
\text { compared to fluoxetine or } \\
\text { curcumin }\end{array}$ & $(1)$ \\
\hline & \multirow{2}{*}{$\begin{array}{l}\text { Randomised, } \\
\text { double-blind, } \\
\text { placebo-controlled } \\
\text { study }\end{array}$} & $\begin{array}{l}56 \text { patients with } \\
\text { major depression }\end{array}$ & $\begin{array}{l}\text { Curcumin }(500 \mathrm{mg}) / \\
\text { placebo for } 8 \text { weeks }\end{array}$ & $\begin{array}{l}\text { Inventory of } \\
\text { Depressive } \\
\text { Symptomatology, } \\
\text { Spielberger State-Trait } \\
\text { Anxiety Inventory }\end{array}$ & $\begin{array}{l}\text { Curcumin showed } \\
\text { significant antidepressant } \\
\text { effect compared to } \\
\text { placebo }\end{array}$ & $(24)$ \\
\hline & & $\begin{array}{l}40 \text { patients with } \\
\text { major depression }\end{array}$ & $\begin{array}{l}\text { Curcumin }(500 \mathrm{mg} / \mathrm{d}) / \\
\text { placebo for } 12 \mathrm{month}\end{array}$ & $\begin{array}{l}\text { Clinical Global } \\
\text { Impression-Severity } \\
\text { Scale, } \\
\text { Hamilton Rating Scale, } \\
\text { Montgomery-Asberg } \\
\text { Depression Rating } \\
\text { Scale. }\end{array}$ & $\begin{array}{l}\text { Extract was effective } \\
\text { similar to imipramine to } \\
\text { citalopram or venlafaxine }\end{array}$ & $(25)$ \\
\hline \multirow[b]{2}{*}{$\begin{array}{l}\text { Ginkgo } \\
\text { biloba }\end{array}$} & \multirow{2}{*}{$\begin{array}{l}\text { Randomised, } \\
\text { double-blind, } \\
\text { placebo-controlled } \\
\text { study }\end{array}$} & $\begin{array}{l}81 \text { patients with } \\
\text { major depressive } \\
\text { disorder }\end{array}$ & $\begin{array}{l}\text { ECT and extract }(40 \mathrm{mg} / \\
8 \mathrm{~h}) / \text { placebo for } 2 \text { weeks }\end{array}$ & $\begin{array}{l}\text { Hamilton depression } \\
\text { questionnaire }\end{array}$ & $\begin{array}{l}\text { Extract was more effective } \\
\text { than placebo }\end{array}$ & (27) \\
\hline & & $\begin{array}{l}27 \text { patients with } \\
\text { seasonal mood } \\
\text { disorder }\end{array}$ & $\begin{array}{l}\text { Ginkgo pills/placebo for } \\
10 \text { weeks }\end{array}$ & $\begin{array}{l}\text { Montgomery-åsberg } \\
\text { Depression Rating } \\
\text { Scale }\end{array}$ & $\begin{array}{l}\text { Extract did not prevent } \\
\text { the development of the } \\
\text { symptoms of winter } \\
\text { depression }\end{array}$ & $(28)$ \\
\hline \multirow[t]{2}{*}{ Chamomile } & $\begin{array}{l}\text { Randomized, } \\
\text { double-blind, } \\
\text { placebo-controlled } \\
\text { study }\end{array}$ & $\begin{array}{l}57 \text { patients with } \\
\text { mixed anxiety and } \\
\text { depression disorder }\end{array}$ & $\begin{array}{l}\text { Placebo/chamomile } \\
\text { capsules }(220 \mathrm{mg} / \mathrm{d}) \text { for } \\
8 \text { weeks }\end{array}$ & $\begin{array}{l}\text { Hamilton Depression } \\
\text { Rating }\end{array}$ & $\begin{array}{l}\text { Extract showed significant } \\
\text { effect compared to } \\
\text { placebo }\end{array}$ & $(6)$ \\
\hline & $\begin{array}{l}\text { Prepost-test } \\
\text { randomized } \\
\text { controlled trial }\end{array}$ & 80 postnatal women & $\begin{array}{l}\text { Chamomile tea or } \\
\text { placebo for } 2 \text { weeks }\end{array}$ & $\begin{array}{l}\text { Edinburgh Postnatal } \\
\text { Depression Scale }\end{array}$ & $\begin{array}{l}\text { Tea showed significant } \\
\text { effect compared to } \\
\text { placebo }\end{array}$ & (31) \\
\hline $\begin{array}{l}\text { Valeriana } \\
\text { officinalis } \\
\text { L. }\end{array}$ & & $\begin{array}{l}2500 \text { patients mild to } \\
\text { moderate depression }\end{array}$ & $\begin{array}{l}\text { St John's-wort }(600 \mathrm{mg}) / \\
\text { Valerian }(100 \mathrm{mg}) / \text { their } \\
\text { combination }\end{array}$ & $\begin{array}{l}\text { Hamilton Depression } \\
\text { Rating }\end{array}$ & $\begin{array}{l}\text { Combination of plants } \\
\text { showed better effects }\end{array}$ & (35) \\
\hline \multirow{3}{*}{$\begin{array}{l}\text { Lavandula } \\
\text { angustifolia }\end{array}$} & Clinical trial & $\begin{array}{l}17 \text { cancer hospice } \\
\text { patients }\end{array}$ & $\begin{array}{l}\text { 3-percent lavender } \\
\text { aromatherapy }\end{array}$ & $\begin{array}{l}\text { 11-point verbal } \\
\text { analogs scale }\end{array}$ & $\begin{array}{l}\text { Aromatherapy showed } \\
\text { significant effect compared } \\
\text { to control }\end{array}$ & (37) \\
\hline & $\begin{array}{l}\text { double-blind } \\
\text { clinical trial }\end{array}$ & $\begin{array}{l}80 \text { patients with } \\
\text { mild to moderate } \\
\text { depression }\end{array}$ & $\begin{array}{l}5 \mathrm{mg} \text { lavender twice } \\
\text { daily }+20 \mathrm{mg} / \mathrm{d} \\
\text { citalopram/ citalopram } \\
\text { for } 8 \text { weeks }\end{array}$ & $\begin{array}{l}\text { Hamilton Depression } \\
\text { Rating }\end{array}$ & $\begin{array}{l}\text { Depression symptoms } \\
\text { were significantly lower in } \\
\text { the case group }\end{array}$ & (38) \\
\hline & $\begin{array}{l}\text { Double-blind, } \\
\text { randomized trial }\end{array}$ & $\begin{array}{l}45 \text { patients with } \\
\text { mild to moderate } \\
\text { depression }\end{array}$ & $\begin{array}{l}\text { Lavender (60 drops) + } \\
\text { placebo/ imipramine } \\
(100 \mathrm{mg})+\text { placebo/ } \\
\text { lavender ( } 60 \text { drops })+ \\
\text { imipramine for } 4 \text { weeks }\end{array}$ & $\begin{array}{l}\text { Hamilton Depression } \\
\text { Rating }\end{array}$ & $\begin{array}{l}\text { Lavender alone showed } \\
\text { lower effect compared to } \\
\text { the imipramine }\end{array}$ & (39) \\
\hline $\begin{array}{l}\text { Echium } \\
\text { amoenum }\end{array}$ & $\begin{array}{l}\text { Double-blind } \\
\text { clinical trial }\end{array}$ & $\begin{array}{l}35 \text { patients with } \\
\text { mild to moderate } \\
\text { depression }\end{array}$ & $\begin{array}{l}\text { Placebo/Echium ( } 375 \\
\mathrm{mg} / \mathrm{d} \text { ) for } 6 \text { weeks }\end{array}$ & $\begin{array}{l}\text { Hamilton Depression } \\
\text { Rating }\end{array}$ & $\begin{array}{l}\text { Echium did not differ } \\
\text { significantly with the } \\
\text { placebo }\end{array}$ & (41) \\
\hline
\end{tabular}

of medicinal plants usually have limitations such as small sample size, use of a single dose of the drug and the short treatment period. The sample size has a significant effect on the study results; if the sample size is small, it would be unlikely to achieve a significant statistical difference. In a number of studies, the antidepressant effects of medicinal plants have been compared with the placebo, while it is better to compare them with common antidepressants in addition to the placebo. The symptoms of the disease have been evaluated before and several weeks after the intervention in most clinical studies conducted on the antidepressant effects of medicinal plants, while some herbs show their effects immediately and some show after a longer period of time. For example, in a clinical trial, curcumin had no significant antidepressant effects until 4 weeks after the treatment; but, its effect appeared from the week 4 to week 8 (24). Therefore, it is recommended to examine the symptoms in a longer treatment period on a weekly basis.

In general, pre-clinical and clinical evaluations of medicinal plants are difficult and complex. One of the major problems in this regard is the production of 
standard herbal medicines with a specific and constant combination with the potential for reproduction. In general, the amount and type of chemical compounds of plants are influenced by various factors such as genetic differences, geographic area, harvest time, soil quality, plant part used, and preparation methods. Thus, the production of herbal drugs with a specific and constant compound is a difficult task. Although performing preclinical studies by using active ingredients of the plant seems effective but they cannot guarantee the efficacy of total extracts in the clinical studies (52).

There are several medicinal products of $H$. perforatum, $M$. recutita, and $V$. officinalis in forms of capsules, pills, and drops on the market that are prescribed for relaxation, anti-anxiety, anti-depression uses and improving the sleep problems. Before presenting the herbs in the form of drugs on the market, their safety has to be determined in numerous studies and legal approvals should be obtained from the Food and Drug Administration or similar organizations for them.

\section{Conclusion}

Some medicinal herbs have shown antidepressant effects similar to those of the conventional antidepressants in the treatment of patients with mild to moderate depression as well as the major depression. Medicinal plants do not have significant side effects in patients and the reported side effects for them are not significantly different from placebo. However, additional studies with a larger sample size are needed to confirm their antidepressant effects, adverse effects and toxicity in different individuals.

\section{Author's contribution}

MS is the single author.

\section{Conflict of interests}

The author declares that there is no conflict of interest.

\section{Ethical considerations}

The ethical issues (including plagiarism, misbehavior, data provision, forgery, duplicate release or submission, redundancy) were fully observed by the author.

\section{Funding/Support}

None.

\section{References}

1. Sanmukhani J, Satodia V, Trivedi J, Patel T, Tiwari D, Panchal $\mathrm{B}$, et al. Efficacy and safety of curcumin in major depressive disorder: a randomized controlled trial. Phytother Res. 2014;28(4):579-85. doi: 10.1002/ptr.5025.

2. Salehi A, Rabiei Z, Setorki M. Effect of gallic acid on chronic restraint stress-induced anxiety and memory loss in male BALB/c mice. Iran J Basic Med Sci. 2018;21(12):1232-7. doi: 10.22038/ijbms.2018.31230.7523.

3. Montazeri A, Mousavi SJ, Omidvari S, Tavousi M, Hashemi
A, Rostami T. Depression in Iran: a systematic review of the literature (2000-2010). Payesh. 2013;12(6):567-94. [Persian]

4. Rabiei Z, Rabie S. A review on antidepressant effect of medicinal plants. Bangladesh J Pharmacol. 2017;12(1):1-11.

5. van Diermen D, Marston A, Bravo J, Reist M, Carrupt PA, Hostettmann K. Monoamine oxidase inhibition by Rhodiola rosea L. roots. J Ethnopharmacol. 2009;122(2):397-401. doi: 10.1016/j.jep.2009.01.007.

6. Amsterdam JD, Shults J, Soeller I, Mao JJ, Rockwell K, Newberg AB. Chamomile (Matricaria recutita) may provide antidepressant activity in anxious, depressed humans: an exploratory study. Altern Ther Health Med. 2012;18(5):449.

7. Agha-Hosseini M, Kashani L, Aleyaseen A, Ghoreishi A, Rahmanpour H, Zarrinara AR, et al. Crocus sativus L. (saffron) in the treatment of premenstrual syndrome: a double-blind, randomised and placebo-controlled trial. Bjog. 2008;115(4):515-9. doi: 10.1111/j.14710528.2007.01652.x.

8. Harrer G, Schmidt U, Kuhn U, Biller A. Comparison of equivalence between the St. John's wort extract LoHyp-57 and fluoxetine. Arzneimittelforschung. 1999;49(4):289-96. doi: 10.1055/s-0031-1300417.

9. Barnes J, Anderson LA, Phillipson JD. St John's wort (Hypericum perforatum L.): a review of its chemistry, pharmacology and clinical properties. J Pharm Pharmacol. 2001;53(5):583-600. doi: 10.1211/0022357011775910.

10. Kasper S, Anghelescu IG, Szegedi A, Dienel A, Kieser M. Superior efficacy of St John's wort extract WS 5570 compared to placebo in patients with major depression: a randomized, double-blind, placebo-controlled, multicenter trial [ISRCTN77277298]. BMC Med. 2006;4:14. doi: 10.1186/1741-7015-4-14.

11. Laakmann G, Schule C, Baghai T, Kieser M. St. John's wort in mild to moderate depression: the relevance of hyperforin for the clinical efficacy. Pharmacopsychiatry. 1998;31 Suppl 1:54-9. doi: 10.1055/s-2007-979346.

12. Philipp M, Kohnen R, Hiller KO. Hypericum extract versus imipramine or placebo in patients with moderate depression: randomised multicentre study of treatment for eight weeks. BMJ. 1999;319(7224):1534-8. doi: 10.1136/ bmj.319.7224.1534.

13. Naghdi Badi H, Amin G, Makizadeh Tafti M, Ziai SA. St. John's wort (Hypericum perforatum L.): a review. Journal of Medicinal Plants. 2005;4(16):1-14. [Persian].

14. Muldner VH, Zoller M. Antidepressive Wirkung eines auf den Wirkstoffkomplex hypericin standardisierten hypericum-extraktes. Arzneim-Forsch. 1984;34:918-20.

15. Hosseinzadeh H, Karimi G, Niapoor M. Antidepressant effect of Crocus sativus L. stigma extracts and their constituents, crocin and safranal, in mice. Acta Hortic. 2004;650:435-45. doi: 10.17660/ActaHortic.2004.650.54.

16. Karimi G, Hosseinzadeh H, Khaleghpanah P. Study of antidepressant effect of aqueous and ethanolic extract of Crocus sativus in mice. Iranian Journal of Basic Medical Sciences. 2001;4(3):153-86. [Persian].

17. Noorbala AA, Akhondzadeh S, Tahmacebi-Pour N, Jamshidi AH. Hydro-alcoholic extract of Crocus sativus L. versus fluoxetine in the treatment of mild to moderate depression: 
a double-blind, randomized pilot trial. J Ethnopharmacol. 2005;97(2):281-4. doi: 10.1016/j.jep.2004.11.004.

18. Akhondzadeh S, Fallah-Pour H, Afkham K, Jamshidi $\mathrm{AH}$, Khalighi-Cigaroudi F. Comparison of Crocus sativus $\mathrm{L}$. and imipramine in the treatment of mild to moderate depression: a pilot double-blind randomized trial [ISRCTN45683816]. BMC Complement Altern Med. 2004;4:12. doi: 10.1186/1472-6882-4-12.

19. Brichenko VS, Kupriyanova IE, Skorokhodova TF. The use of herbal adaptogens together with tricyclic antidepressants in patients with psychogenic depressions. Modern Problems of Pharmacology and Search for New Medicines. 1986;2:58-60.

20. Darbinyan V, Aslanyan G, Amroyan E, Gabrielyan E, Malmström C, Panossian A. Clinical trial of Rhodiola rosea L. extract SHR-5 in the treatment of mild to moderate depression. Nord J Psychiatry. 2007;61(5):343-8. doi: 10.1080/08039480701643290.

21. Mao JJ, Xie SX, Zee J, Soeller I, Li QS, Rockwell K, et al. Rhodiola rosea versus sertraline for major depressive disorder: a randomized placebo-controlled trial. Phytomedicine. 2015;22(3):394-9. doi: 10.1016/j. phymed.2015.01.010.

22. Kelly GS. Rhodiola rosea: a possible plant adaptogen. Altern Med Rev. 2001;6(3):293-302.

23. Kulkarni S, Dhir A, Akula KK. Potentials of curcumin as an antidepressant. ScientificWorldJournal. 2009;9:1233-41. doi: $10.1100 /$ tsw.2009.137.

24. Lopresti AL, Maes M, Maker GL, Hood SD, Drummond PD. Curcumin for the treatment of major depression: a randomised, double-blind, placebo controlled study. J Affect Disord. 2014;167:368-75. doi: 10.1016/j.jad.2014.06.001.

25. Bergman J, Miodownik C, Bersudsky Y, Sokolik S, Lerner PP, Kreinin A, et al. Curcumin as an add-on to antidepressive treatment: a randomized, double-blind, placebo-controlled, pilot clinical study. Clin Neuropharmacol. 2013;36(3):73-7. doi: 10.1097/WNF.0b013e31828ef969.

26. Diamond BJ, Bailey MR. Ginkgo biloba: indications, mechanisms, and safety. Psychiatr Clin North Am. 2013;36(1):73-83. doi: 10.1016/j.psc.2012.12.006.

27. Nikfarjam M, Goudarzi I, Heidari S, Rafiee Vardanjani L, Parvin N. Effect of Ginkgo biloba pill on patients with major depression treated with electroconvulsive therapy. Journal of Mazandaran University of Medical Sciences. 2012;22(88):61-9. [Persian].

28. Lingaerde O, Føreland AR, Magnusson A. Can winter depression be prevented by Ginkgo biloba extract? a placebocontrolled trial. Acta Psychiatr Scand. 1999;100(1):62-6. doi: 10.1111/j.1600-0447.1999.tb10915.x.

29. Hemmeter U, Annen B, Bischof R, Brüderlin U, Hatzinger $\mathrm{M}$, Rose $\mathrm{U}$, et al. Polysomnographic effects of adjuvant Ginkgo biloba therapy in patients with major depression medicated with trimipramine. Pharmacopsychiatry. 2001;34(2):50-9. doi: 10.1055/s-2001-15182.

30. Cohen AJ, Bartlik B. Ginkgo biloba for antidepressantinduced sexual dysfunction. J Sex Marital Ther. 1998;24(2):139-43. doi: 10.1080/00926239808404927.

31. Chang SM, Chen $\mathrm{CH}$. Effects of an intervention with drinking chamomile tea on sleep quality and depression in sleep disturbed postnatal women: a randomized controlled trial. J Adv Nurs. 2016;72(2):306-15. doi: 10.1111/jan.12836.
32. Srivastava JK, Shankar E, Gupta S. Chamomile: a herbal medicine of the past with bright future. Mol Med Rep. 2010;3(6):895-901. doi: 10.3892/mmr.2010.377.

33. Setorki M, Moshfegh A, Raoufi N. Effect of hydroalcoholic extract of Matricaria chamomilla on passive avoidance memory and pain induced by global cerebral ischemia in Wistar rat. Journal of Shahrekord University of Medical Sciences. 2016;17(6):76-86. [Persian].

34. Jacobs BP, Bent S, Tice JA, Blackwell T, Cummings SR. An internet-based randomized, placebo-controlled trial of kava and valerian for anxiety and insomnia. Medicine (Baltimore). 2005;84(4):197-207. doi: 10.1097/01. md.0000172299.72364.95.

35. Müller D, Pfeil T, von den Driesch V. Treating depression comorbid with anxiety--results of an open, practiceoriented study with St John's wort WS 5572 and valerian extract in high doses. Phytomedicine. 2003;10 Suppl 4:2530. doi: 10.1078/1433-187x-00305.

36. Taavoni S, Ekbatani N, Kashaniyan M, Haghani H. Effect of valerian on sleep quality in postmenopausal women: a randomized placebo-controlled clinical trial. Menopause. 2011;18(9):951-5. doi: 10.1097/gme.0b013e31820e9acf.

37. Louis M, Kowalski SD. Use of aromatherapy with hospice patients to decrease pain, anxiety, and depression and to promote an increased sense of well-being. Am J Hosp Palliat Care. 2002;19(6):381-6. doi: 10.1177/104990910201900607.

38. Nikfarjam M, Parvin N, Asarzadegan N. The effect of Lavandula angustifolia in the treatment of mild to moderate depression. Journal of Shahrekord University of Medical Sciences. 2010;11(4):66-73. [Persian].

39. Akhondzadeh S, Kashani L, Fotouhi A, Jarvandi S, Mobaseri M, Moin M, et al. Comparison of Lavandula angustifolia Mill. tincture and imipramine in the treatment of mild to moderate depression: a double-blind, randomized trial. Prog Neuropsychopharmacol Biol Psychiatry. 2003;27(1):123-7. doi: 10.1016/s0278-5846(02)00342-1.

40. Ranjbar A, Khorami S, Safarabadi M, Shahmoradi A, Malekirad AA, Vakilian K, et al. Antioxidant activity of Iranian Echium amoenum Fisch \& CA Mey flower decoction in humans: a cross-sectional before/after clinical trial. Evid Based Complement Alternat Med. 2006;3(4):469-73. doi: 10.1093/ecam/nel031.

41. Sayyah M, Boostani H, Pakseresht S, Malaieri A. Efficacy of aqueous extract of Echium amoenum in treatment of obsessive-compulsive disorder. Prog Neuropsychopharmacol Biol Psychiatry. 2009;33(8):15136. doi: 10.1016/j.pnpbp.2009.08.021.

42. Chen Y, Han T, Qin L, Rui Y, Zheng H. [Effect of total triterpenes from Centella asiatica on the depression behavior and concentration of amino acid in forced swimming mice]. Zhong Yao Cai. 2003;26(12):870-3.

43. Cioanca O, Hritcu L, Mihasan M, Trifan A, Hancianu M. Inhalation of coriander volatile oil increased anxiolyticantidepressant-like behaviors and decreased oxidative status in beta-amyloid (1-42) rat model of Alzheimer's disease. Physiol Behav. 2014;131:68-74. doi: 10.1016/j. physbeh.2014.04.021.

44. Moghaddam F, Asle-Rousta M. Anxiolytic and antidepressant effects of summer savory (Satureja hortensis) hydroalcoholic extract in male rats exposed to chronic restraint stress. Daneshvar Medicine. 2016;24(125):31-9. 
[Persian].

45. Dang H, Chen Y, Liu X, Wang Q, Wang L, Jia W, et al. Antidepressant effects of ginseng total saponins in the forced swimming test and chronic mild stress models of depression. Prog Neuropsychopharmacol Biol Psychiatry. 2009;33(8):1417-24. doi: 10.1016/j.pnpbp.2009.07.020.

46. Qazi N, Khan RA, Rizwani GH. Evaluation of antianxiety and antidepressant properties of Carthamus tinctorius L. (Safflower) petal extract. Pak J Pharm Sci. 2015;28(3):9915.

47. El Mansouri L, Bousta D, El Youbi-El Hamsas A, Boukhira $\mathrm{S}$, Akdime $\mathrm{H}$. Phytochemical screening, antidepressant and analgesic effects of aqueous extract of Anethum graveolens L. from southeast of Morocco. Am J Ther. 2016;23(6):e1695-e9. doi: 10.1097/mjt.0000000000000090.

48. Mahmoudi R, Zanganehnejad Z, Setorki M. Effect of hydroalcoholic extracts of thyme on movement disorders, depression and pain caused by the injection of 6-hydroxydopamine in rat model of Parkinson's. Journal of Babol University of Medical Sciences. 2017;19(1):48-54. doi: $\quad$ 10.22088/jbums.19.1.48.

49. Singh B, Singh D, Goel RK. Dual protective effect of Passiflora incarnata in epilepsy and associated post-ictal depression. J Ethnopharmacol. 2012;139(1):273-9. doi: 10.1016/j.jep.2011.11.011.

50. Emamghoreishi M, Talebianpour MS. Antidepressant effect of Melissa officinalis in the forced swimming test. Daru. 2009;17(1):42-7.

51. Machado DG, Bettio LE, Cunha MP, Capra JC, Dalmarco JB, Pizzolatti MG, et al. Antidepressant-like effect of the extract of Rosmarinus officinalis in mice: involvement of the monoaminergic system. Prog Neuropsychopharmacol Biol Psychiatry. 2009;33(4):642-50. doi: 10.1016/j. pnpbp.2009.03.004.

52. Saki K, Bahmani M, Rafieian-Kopaei M. The effect of most important medicinal plants on two importnt psychiatric disorders (anxiety and depression)-a review. Asian Pac J Trop Med. 2014;7S1:S34-42. doi: 10.1016/s19957645(14)60201-7. 